\title{
Rendészeti tisztképzés a Rendőrtiszti Föiskola megalakulásáig
}

\section{SALLAI János ${ }^{1 \odot}$}

\begin{abstract}
A modern magyar rendészet kialakulásával párhuzamosan kezdetét vette a fövárosi, majd a vidéki rendőrségek államosítása. Az egységes államrendőrség megléte egységes tisztképzésen alapuló rendőrtisztviselői felkészítést igényelt, amelynek megteremtésére 1922-ben került sor. Ezzel elindult a felügyelői, fogalmazói és detektív kar felsőfokú képzése, amely a II. világháború végéig tartott. A II. világháború után Magyarország szovjet érdekövezet alá került, aminek eredményeként a rendészetben is a szovjet modell megvalósítására került sor. Így a munkás és paraszt fiatalok rendőrtisztté való felkészítése elöször gyorstalpalókon keresztül valósult meg, majd 1948-tól rendőr akadémiákon. A társadalmi fejlödés eredményeként a rendöri tevékenységgel szemben is megnövekedtek az igények, amire az adott politikai vezetés 1971-től a Rendőrtiszti Föiskola felállitásával válaszolt.
\end{abstract}

Kulcsszavak: rendőrtiszt, rendőr tisztviselö, oktatás, képzés, felügyelö, detektív, fogalmazó, rendőrség, szaktanfolyam

\section{A magyar rendőrtisztképzés előzményei}

A magyar rendőrtisztképzés előzményeihez mindenképp hozzátartozik, hogy az egységes országos állami rendőrség gondolata és első elméleti lépése Karvasy Ágoston 1843-1844-ben megjelent múvéhez, ${ }^{2}$ illetve gyakorlati kivitelezése Szemere Bertalanhoz, ${ }^{3}$ az 1848-1849-es forradalom és szabadságharc belügyminiszteréhez köthető. $\mathrm{Az}$ ismert történelmi körülmények miatt az országos rendőrség javaslatának beteljesedése elmaradt, majd a kiegyezés (1867) után elindult egy szakmai vita, hogy legyen-e, és ha igen, akkor milyen állami rendőrség legyen Magyarországon. A szakmai döntések következtében eldőlt, hogy Magyarországon állami rendőrség lesz, amelynek első lépéseként az egyesült főváros rendőrségét 1873-tól a Belügyminisztérium alá

Sallai János PhD, r. ezredes, Nemzeti Közszolgálati Egyetem Rendészettudományi Kar, Rendészetelméleti és Történeti Tanszék, tanszékvezető egyetemi tanár.

János Sallai, PhD, Police Colonel, University of Public Service, Department of Law Enforcement Theory and Law Enforcement History, Head of Department, Professor.

E-mail: sallai.janos@uni-nke.hu

2 Karvasy Ágoston: A politicai tudományok rendszeresen előadva I-III. Győr, Streibig, 1843-1844.

3 „A Budapesten belügyminiszterileg felállított országos rendőri osztály igazgatásával Hajnik Pál miniszteri tanácsnok bízatott meg." Forrás: https://hu.wikipedia.org/wiki/Hajnik_P\%C3\%A11_(rend\%C5\%91rf\%C5\%91n\%C3\%B6k) 
rendelték. Ezt követően 8 év múlva, az 1881. XXI. törvénycikk ${ }^{4}$ kiadásával megtörtént az első állami rendőrségünk szervezetének és tevékenységének korszerű szabályozása. Ezzel párhuzamosan a városainkban az „ahány ház annyi szokás” elve alapján municipális rendőrségek tartották fenn a rendet, köznyugalmat, minden városban más-más egyenruhában, elnevezéssel, díjazással.

A rendőrtisztek képzésében az első meghatározó jogszabály az 1883. évi I. törvény ${ }^{5}$ volt, amely a caeteris paribus elvét szem előtt tartva, már a rendőrtisztviselők felvételekor jogi, államtudományi képzettséget írt elő a kapitányi, felügyelői tisztviselők számára. A törvény beterjesztésénél mintaként a német területeken alkalmazott gyakorlatokat említették, ahol például a württembergi királyságban ${ }^{6}$ a rendészettan (Polizeiwissenschaft) ismeretekből felsőbb kategóriai tantárgyként felvételi vizsgát is kellett tenniük a tisztviselő jelölteknek. A fővárosi rendőrségnél a főkapitánynak, a rendőrtanácsosoknak, a kerületi kapitányoknak, a főkapitányi titkárnak és a fogalmazóknak, illetve a városi rendőrségeknél a kapitányoknak már a felvételikor rendelkezniük kellett az alábbi végzettséggel:
„a) ügyvédi oklevél, vagy
b) államtudományi, vagy
c) jogtudományi tudorság, vagy végre
d) legalább a jogi négy évi tanfolyamnak a fennálló szabályok szerint való bevég- zése, és az államtudományi államvizsgának sikeres letétele." ${ }^{7}$

A rendészeti oktatás, illetve egy rendészeti iskola létrehozása a szakmai berkeken belül, már a kiegyezést követően mindig a szakmai közérdeklődés központjában állt, amelyet igazol az első rendészeti szakfolyóiratban ${ }^{8}$ közölt főszerkesztői cikk, továbbá az 1872-ben megjelent Közrendészeti Lap 40. számának címoldalán található Rendészeti Iskola vezércikke. Az utóbbi cikkben a szerző szerint, mivel a rendőrség szakmunkákkal, értsd: szakirodalommal nem rendelkezik, ezért a közigazgatásban részt vevő rendőröket az alapoktól kezdve meg kell ismertetni a rendészettel, és a feladat végrehajtását egy rendészeti tanszék felállításával kell kezdeni. Továbbá, a szerző véleménye szerint csak a képzett rendőr alkalmas arra, hogy a jogszabályokat betartassa. A rendészeti képzés továbbgondolásáról írt Rédey Miklós 1894-ben a Rendöri Lapok november 4-ei számában, amelyben a rendőrtisztviselők önképzését tartotta szükségesnek, és ahhoz eszközként egy rendőrségi könyvtár felállítását javasolta. A municipális rendőrség bajait abban látta, hogy az állományában kevés a kvalifikált rendőrtisztviselő, ezért a helyzet kezelésére - Rédey szerint - a közigazgatási tanfolyamok elindítása jelenthetett megoldást.

\footnotetext{
1881. évi XXI. törvénycikk a Budapest-fővárosi rendőrségről.

1883. évi I. törvénycikk a köztisztviselők minősítéséről.

1883. évi I. törvénycikk indokolása a köztisztviselők minősítéséről.

1883. évi I. törvénycikk a köztisztviselők minősítéséről.

Sallai János: Első rendészetelméleti szakközlöny folyóiratunk: a „Közbiztonság” (1869). In Gaál Gyula - Hautzinger Zoltán (szerk.): A határrendészettôl a rendészettudományig. Pécs, MHT Határőr Szakosztály Pécsi Szakcsoportja, 2016. 271-274.
} 
A rendőrségeknél - az államinál és a municipálisnál egyaránt - a végrehajtó állomány felkészítése, oktatása jelentette a legnagyobb problémát, amelyet a felkészült rendőrtisztviselők, oktató tisztek jól megoldottak. Mivel azonban a tanulmány témája a tisztviselő-, illetve rendőrtisztképzés, ezért, és terjedelmi korlátok miatt, a legénység és altiszti állomány képzésével nem foglalkozom.

A rendőrtisztviselők képesítésének a közigazgatási tisztviselőkkel azonos besorolását a korszak rendészeti szakértelmisége folyamatosan kritizálta. Ennek okát Rédey Miklós ${ }^{9}$ abban látta, hogy a rendészettel, rendőrséggel az elméleti jogtudósok nem foglalkoztak kellő mélységben, továbbá, hogy a rendészet fogalmát nem tisztázták, így a közigazgatással való kapcsolatát sokan összekeverték. A kialakult helyzetet jellemzi, hogy

„a rendőrtisztviselők még a közigazgatási pályára lépőknél is rosszabb helyzetben vannak, mert csakis közigazgatási ismeretekkel lépnek be állásukba s mindjárt az első szárnypróbálgatásoknál szomorú tapasztalatokra jutnak. Még jó, ha meg nem égetik a körmüket. A rendészetnek tanszéke nincs. De még csak special kollégiumként sem szerepel soha a tanrendekben. A rendészettel a közigazgatásról szóló tankönyvek öszsze-vissza 6-8 oldalon végeznek, felszínesen, rendszerint, a 1860-70-es évek német tudósainak elavult theoriái nyomán. Önálló, csakis rendészettel foglalkozó tankönyvünk nincs, sem elméleti, sem gyakorlati". ${ }^{10}$

Az előbbiekben leírtaktól csak egy kivételt említ meg Rédey, mégpedig Concha Győző akadémiai székfoglalóját. A korszak rendészeti szakértelmisége felismerte, hogy a rendőrség feladatainak magas színvonalon való végrehajtásához a személyi állomány képzésén keresztül vezet az út. Ennek szellemében írta Laky Imre ${ }^{11}$ az 1906-os tankönyvében:

„A rendőrközeget úgy kell kiképeznünk, hogy tudja, ismerje azt a nagy hatalmát, mellyel a törvények felruházták; hogy megértse azt a legszentebb jogát, midőn megszólítás, figyelmeztetés által megelőzi a kihágásokat, bűncselekményeket. Ha hivatásának eme magaslatára tud emelkedni, akkor nem unottan fogja teljesíteni a szolgálatot; nem fogja a közösséget indokolatlanul zaklatni, hanem lesz, amivé lennie kell: a törvényekben megállapított rendnek szakképzett őre."12

Úgy gondolom Laky Imre szavai a mai napig útmutatóul szolgálhatnak a rendészeti képzésben részt vevő tiszti és oktatói állománynak egyaránt. A rendőri szak-

\footnotetext{
Rédey Miklós: Rendőri szakoktatás. Közbiztonság, 18. (1911), 7. 98.

Rédey (1911): i. m. 98.

11 Laky Imre könyvének kiadása időszakában a rendőrfelügyelő, a fő- és székvárosi m. kir. Államrendőrség Tanosztályának parancsnoka volt. Több tankönyv, a két rendőrségi lexikon szerzője, társszerzője és sok rendészeti témájú publikáció írójaként nagyon sokat tett a rendészetelmélet és -gyakorlat magas színvonalon való múveléséért.

12 Laky Imre: Rendőrközegek tankönyve. Budapest, Pátria, 1906. 6.
} 
képzés fontosságát jelezte, hogy az 1912. évi LVIII. törvénycikk alapján kibocsátott 41.500/1913. BM rendelet Budapesten vidéki oktató rendőrtiszteket és altiszteket képző tanfolyamok megtartását rendelte el, a rendőrképzés egységes színvonalának biztosítása érdekében.

Az Osztrák-Magyar Monarchia utolsó évtizedében a rendőrtisztek és altisztek képzésére a következő oktatási és továbbképzési intézmények álltak rendelkezésre:

- Rendőri iskola;

- Altiszti iskola;

- Detektíviskola;

- Dactiloscopiai tanfolyam;

- Bünügyi értekezletek. ${ }^{13}$

Amint látható, a tisztviselők, fogalmazók, felügyelők képzésére, továbbképzésére csak az 1907-től bevezetett bünügyi értekezletek keretén belül nyílt mód. Ezeken a rendezvényeken a fő cél a testület szellemének ápolása, szakmai ismeretek pótlása, hibák feltárása, megbeszélése, bűnügyi, vagy más rendészeti kérdésekben állásfoglalások kialakítása volt. 1910-ben a bűnügyi értekezleteken a következő témákat tárgyalták meg:

- a büntető novella;

- országos búnügyi nyilvántartás helyzete;

- bünügyi értesítők reformja;

- személyiség szerepe a nyomozásban;

- magánjogi igények;

- bűntettek üldözése belföldön és külföldön;

- idegen állampolgárokkal való érintkezés szabályai;

- büntető statisztika fontossága;

- nyomozás sajtóügyekben;

- Államrendőrség fegyverhasználata;

- az uzsora;

- krimináltaktika és -technika kérdései. ${ }^{14}$

\section{A rendörség központosítása és államosítása}

A 20. század elején a közbiztonság, rendészet kapcsán, a rendőrség vezetőit, tisztviselőit, továbbá a politikai élet szereplőit egyaránt a rendőrség államosítása és centralizálása foglalkoztatta. A bekövetkezett nagy háború, majd forradalmak ugyan egy időre elodázták az államosítást, de arra az 1919-ben kiadott 5047-es ME törvénypótló rendelettel 1920-tól sor került. A centrális állami rendőrség létrehozása után a ma-

\footnotetext{
A rendőrség intézményei. Közbiztonság, (1911), 42. 521-527.

14 A rendőrség intézményei (1911): i. m. 521-527.
} 
gyar rendőrségnél szabályozták az állományviszonyokat és a feltölthető létszámot. A 102.837/1922-es BM rendelet szerint a rendőrség szervezeti felépítése ekkor a következő volt.

- legfelsőbb igazgatás;

- kerületi rendőr-főkapitányságok;

- rendőr-főkapitányságok;

- rendőri kirendeltségek;

- határszéli kirendeltségek.

A rendőrség akkori állományának összetételét az alábbiakban szabályozta a rendelet:

a) Egyenruha és fegyver viselésére jogosultak:

- fogalmazói kar; ${ }^{15}$

- felügyelői kar; ${ }^{16}$

- őrségi személyzet (altisztek és rendőrök).

A fentiek által betöltött státuszok a 12 ezer főt nem haladhatták meg. A fogalmazói és felügyelői karhoz tartozó egyenruhás állomány jelentette a rendőrség tiszti rangú tisztviselőit, számuk az 1500-at nem léphette át.

Ebben az időben a rendőrtiszt vagy tisztviselő elnevezés a szakirodalomban, rendeletekben vegyesen fordul elő. Nyugat-Európában a rendőrtiszten általában a csapattisztet értették, míg a tisztviselőn az adminisztratív ügyeket végző alkalmazottakat. „Ez a több évtizedes múltjára és hagyományaira joggal büszkélkedő magyar rendőrség a maga tisztikarának tagjaiban mindenkor tiszteket látott, akik a féltő gonddal őrzött testületi tekintély védelmében és gyarapításában éppúgy elől jártak, mint a reájuk bízott alárendelteknek magyar katonás szellemben, az ősök példájára való nevelésében."17 Ugyanakkor a két világháború között a képzésre vonatkozó ME és BM rendeletekben a rendőrtisztviselő, fogalmazó, felügyelő, detektív megnevezéseket használták. Ennek oka lehetett a trianoni békediktátum hatálybalépését követő rejtés időszaka, valamint a rendőrség mint polgári közigazgatási szervezet szimbolikus megerősítése, amellyel következetesen kerülték a rendőrtiszt elnevezések használatát. Ebben változás az 1940-es évektől következett be, amelytől kezdve „teljesen jogszerűen, egységesen és általánosan a m. kir. rendőrség fogalmazói és felügyelői tisztikarának tagjait - hivatásuknál és tiszti állásuknál fogva - vitán felül megillető »rendőrtiszt « elnevezést"18 mind a szabályzatokban, mind a rendeletekben és a hétköznapok során alkalmazták.

\footnotetext{
15 Fogalmazó: az intéző, rendőrség állományában, a rendőrtisztviselők legnagyobb csoportját alkotó fogalmazói karban rendszeresített rendfokozat volt 1944-ig. Boda József (főszerk.): Rendészettudományi szaklexikon. Budapest, Dialóg Campus, 2019. 200.

16 Felügyelő: végrehajtó rendőrség állományában, a főparancsnok irányítása alatt szolgálatot teljesítő csapattisztek (felügyelői kar) rendfokozatának elnevezése volt 1944-ig. Boda (főszerk.) (2019): i. m. 191.

17 Tiszt vagy tisztviselő. Magyar Rendôr, 8. (1941), 10. 1.

18 Tiszt vagy tisztviselő (1941): i. m. 1.
} 
b) Egyenruha és fegyver viselésére nem jogosultak:

- orvosok;

- irodai alkalmazottak;

- detektívek;

- kézbesítő szolga személyzet.

A fenti személyzet létszáma 4000 fő lehetett. ${ }^{19}$

A rendőrség felügyelői és fogalmazói karába való bekerülés csak a magas követelmények teljesítése, valamint a képzési rendszernek megfelelő tanfolyamok és vizsgák eredményes teljesítése után vált lehetővé a pályázó számára. A helyzet fontosságát jelzi, hogy a rendőrség felügyelői és fogalmazói karának feltöltésével kapcsolatos követelményeket miniszterelnöki, majd annak végrehajtását belügyminiszteri rendeletekben fogalmazták meg. ${ }^{20}$

Meghatározó volt, hogy akkor az országos szaktanulmányi felügyelői beosztást az a Dr. Dorning Henrik töltötte be, aki szívügyének tekintette a rendőrség képzését, aki több nyelven beszélő és publikáló felkészült rendőrtiszt volt, és aki 1911-ben Temple Rezsővel Németországban, Franciaországban, valamint Ausztriában járt szakmai tanulmányúton. Az I. világháború után a magyar rendészeti oktatás megszervezésében nagy figyelmet fordítottak a nyugat-európai modellek tanulmányozására. Ebben az időszakban, az Egyesült Királyságban már rendőrképző főiskolát, egyetemet ${ }^{21}$ terveztek felállítani, Németországban pedig megszervezték a tisztképzést, és megrendezték a rendőrtudományok ${ }^{22}$ hetét Berlinben.

A korábbi sokszínű vidéki rendőrségek és a két eltérő profilú állami rendőrség igazgatási egysége azonban ekkor még nem jelenthette azt, hogy teljes mélységben sikerült az egységes állami rendőrséget létrehozni. Anyagi és technikai nehézségek miatt a fegyverzet, valamint a ruházat egységes ellátását nagyon nehéz volt megoldani, valamint az egységes gondolkodás megteremtése is kihívás volt az akkori belügyi rendőri vezetők számára. Ezek megvalósításának szükségességét nagyon jól látta az akkori politikai, rendészeti, rendőri vezetés. Emellett felül kellett vizsgálni egy korábbi helytelen szabályozást, ${ }^{23}$ amely a rendőrtisztviselőknek és a közigazgatási tisztviselőknek azonos képesítést írt elő. Ugyanakkor az 1883. évi I. a köztisztviselők minősítéséről szóló törvény 29. §-a $\mathrm{a}^{24}$ lehetőséget adott a minisztériumoknak, hogy speciális köve-

\footnotetext{
19 Sallai János: A magyar rendészeti képzés története 1922-2017. Rendőr altiszt (tiszthelyettes) és rendőrtiszt képzés a XX-XXI században. In Czene-Polgár Viktória - Zsámbokiné Ficskovszky Ágnes (szerk.): Mérföldkövek az adó- és vámigazgatás történetéból: Válogatott tanulmányok az évfordulók tükrében. Budapest, Magyar Rendészettudományi Társaság Vám- és Pénzügyőri Tagozat, 2017. 86-123.

20 Sallai János: A magyar rendészettudomány etablációja és akkreditációja. In Ruzsonyi Péter (szerk.): Fenntartható biztonság és társadalmi környezet tanulmányok III. Budapest, Ludovika Egyetemi Kiadó, 2020. 13-130.

$21 \quad$ MTI jelentés 1930. július 16.

22 Dorning Henrik: Berlini rendőrkiállítás. A Rend, (1926), 77. 2.

23 Rédey Miklós: Rendőri szakoktatásunk. Rendőri Lapok, 9. (1902), 16. 121-122.

24 E szerint: „Az egyes ministeriumok kebelében a tőlük függő egyes állami hivatalokra nézve eddig fennállott, vagy a mutatkozó szükség szerint ezentul életbeléptetendő különleges tiszti vizsgák a fentebbi rendelkezések által nem érintetnek." 1883. évi I. törvénycikk 29. §.
} 
telményeket támasszanak a saját köztisztviselőjükkel szemben. Ez az úgynevezett „minősítési törvény” a közigazgatási szakba sorolt rendőrtisztviselői állások többségének betöltéséhez felsőfokú végzettséget írt elő. A jelentkezőnek ügyvédi oklevéllel, államtudományi vagy jogtudományi tudorsággal, vagy legalább a négyéves jogakadémiai tanfolyam elvégzésével és államtudományi államvizsgával kellett rendelkeznie. A véglegesített tisztviselő tanulmányai azonban ezzel nem értek véget: „Már régóta felismerték azt az igazságot, hogy a rendőrség intéző és végrehajtó tisztviselői, valamint külszolgálati közegei részére nem elegendő az az előképzettség, amelyet valamely alsóbb vagy középfoku iskola, vagy akár az egyetem adhat, hanem feladatkörük sajátosságánál fogva külön szakképzésre szorulnak" - említi Dorning Henrik egyik 1922-es előadásában. ${ }^{25}$

\section{A rendörtisztviselöi szaktanfolyamok}

Az 1883. évi I. törvénnyel összhangban 1922. április 27-én kiadták gróf Bethlen István miniszterelnök 3.720. sz. rendeletét „a rendőri szolgálat fogalmazói és felügyelői szakában való alkalmazásához szükséges kellékek és ezek joghatálya" címmel. A rendelet szerint a felügyelői és fogalmazói karban csak azt lehetett alkalmazni, aki sikeresen teljesítette a rendőrtisztviselői tiszti vizsga követelményeit. Ilyen vizsgát pedig az tehetett, aki egyéves próbaszolgálat után sikeresen felvételizett. A próbaszolgálathoz a következő követelmények teljesítését írta elő a rendelet:

„a) magyar állampolgár (1879: L. törvénycikk);

b) gondnokság, csőd alatt nem áll, bủntett vagy vétség miatt vád alá helyezve vagy általában szabadságvesztés büntetése alatt nincs, nyereségvágyból eredő bűntett vagy vétség miatt elitélve nem volt, hivatalvesztésre szóló ítélet hatálya alatt nem áll, s erkölcsi tekintetben alapos kifogás alá nem esik"26

c) 21 évet meghaladó, de 30 éven aluli életkor

d) nőtlen állapot

e) erős testalkat és egészséges szervezet

f) a fogalmazói karhoz pályázóknál a jogi és államtudományi tanulmányoknak valamely magyar egyetemen vagy jogakadémián történt szabályszerű elvégzése és a jogtudományi vagy államtudományi államvizsgának sikeres letétele, vagy pedig valamely magyar egyetemen a jogtudori vagy államtudori oklevél megszerzése, - a felügyelői karhoz pályázóknál pedig valamely hazai középiskolai érettségi vizsga vagy a középiskolákkal tanértékre nézve egyenlőnek tekintendő szakiskola vagy katonai (hadapród) iskola, képesítő vizsgája.

g) rendezett anyagi viszonyok, vagy legalább adósságtól mentesség." ${ }^{27}$

\footnotetext{
25 Androvicz Gábor: A magyar rendőrképzés fejlődése a dualizmus időszakában. Magyar Rendészet, 18. (2018), 1.31.

26 1883. évi I. törvénycikk a köztisztviselők minősítéséről.

27 3.720/1922. sz. M. E. rendelet, a rendőri szolgálat fogalmazói és felügyelői szakában való alkalmazásához szükséges kellékek és ezek joghatálya.
} 
Az életkor és a nőtlenség tekintetében, kivételes esetben a belügyminiszter engedélyével el lehetett térni.

A rendészeti tisztviselővé válás tehát a próbaszolgálattal kezdődött, amelyet a minden év nyarán meghirdetett pályázatra való jelentkezéssel lehetett indítani. A Trianon utáni helyzetet jól illusztrálja, hogy a jelentkezők magyar állampolgársága és a származási helye külön igazolandó volt. Ha valaki az elszakított területről származott, az állampolgárság igénylésére megtett okmány elég volt az igazolásra. A többi feltételnek való megfelelést a kiadott okmányokkal, vagy például a nőtlenséget vagy az adósságmentességet nyilatkozattal kellett igazolni a pályázónak. De ezenfelül nyilatkozni kellett arról is, ha még egy (idegen) nyelvet beszélt a próbaszolgálatra jelentkező személy. A próbaszolgálat rendőrségi helyszínét megnevezhette a jelölt. A testi, fizikai, egészségügyi alkalmasságot rendőrorvos állapította meg. ${ }^{28}$

A próbaszolgálatra sikeresen pályázó személyt a próbaszolgálat alatt ideiglenesen segédfogalmazóvá és segédfelügyelővé lehetett kinevezni, amelynek szolgálati ideje véglegesítés esetén beleszámított a tényleges szolgálatban eltöltött időbe. A nevezettek a próbaszolgálat alatt egyenruhát nem viselhettek, és onnan bármikor elbocsáthatók voltak, anyagi igényt a rendőrséggel szemben nem támaszthattak.

A próbaszolgálat leteltével a jelöltek a szolgálati idejük alatt szerzett szakmai tapasztalataikról és az elméleti felkészültségükről, továbbá az általános múveltségükről felvételi vizsga keretén belül adtak számot. Aki sikeres vizsgát tett, véglegesítették, és folytathatta az egyéves szaktanfolyamon a szolgálatot, akinek nem sikerült, annak távoznia kellett a rendőrségtől. A rendőrtisztviselői tiszti tanfolyamot ${ }^{29}$ Budapesten szervezték meg, amelynek elsô ünnepélyes megnyitójára Budapesten 1920. november 22-én ${ }^{30}$ szerdán, az (Üllői úti) Mária Terézia laktanya nagytermében került sor. ${ }^{31} \mathrm{Az}$ ünnepségen - a rendezvény jelentőségéhez illően - a részt vevő rendőrök díszegyenruhában jelentek meg. Az ünnepség helyszínére elsőként Dorning Henrik országos szaktanulmányi felügyelő, Laky Imre főfelügyelő, a szaktanfolyamok parancsnoka és a tanári kar vonult be. Ezt követően a következő meghívott vendégek foglalták el a helyüket: Pekáry Ferenc ny. miniszteri tanácsos, Máriássy Barna BM államtitkár, Tóth Géza, Tomcsányi Kálmán, Szentgyörgyi Kálmán, Vecsey József, Vay Kázmér, Siket Andor, BM miniszteri tanácsnokok, Marinovich Jenő, a budapesti államrendőrség főkapitánya, továbbá a kerületi kapitányok és a számvevőség főnöke. Az ünnepségen a kormányt Rakovszky Iván belügyminiszter képviselte, aki Nádosy Imre országos főkapitány kíséretében érkezett meg. Az ünnepségen Nádosy Imre országos főkapitány és Dorning Henrik a beszédeikkel emlékezetessé tették ezt a napot,

\footnotetext{
28 Sallai János: Rendőr altiszt- és tisztképzés a m. kir állami rendőrségnél az államosítás (1920) után. In Varga János (szerk.): A határrendészeti tisztképzés negyedszázada. Budapest, Dialóg Campus, 2017. 239-253.

29 Barcza Pál: A Magyar Királyi Rendôrség szervezete és ügyvitele. Rendőriskolák tananyagának tára. V. kötet. Budapest, BM, 1928. 48-63.

30 Ma november 22. az NKE RTK kari napja.

31 Az országos szaktanfolyam megnyitó ünnepe. A Rend, 2. (1920), 176. 1.
} 
amellyel kezdetét vette a korszerű rendőrtisztképzés, „egy új és korszakos jelentőségű kulturális szervezet, más szóval rendőrfőiskola, a rendőr akadémia”. ${ }^{32}$

Ezzel intézményesített keretek között kezdetét vette Magyarországon a felsőfokú rendőrtisztképzés, ${ }^{33}$ amely a jövő generációit felkészítette a rendészeti, vezetési, rendőri szakmai feladatok végrehajtására. Ennek érdekében a korszak jeles rendőrtudósai a korábbi szakmai tapasztalataikra, külföldi tanulmányúton szerzett ismereteikre támaszkodva tankönyveket írtak és adtak ki. A rendőri vezetői állomány a leendő rendőrtiszteket az önképzésre, általános és szakmai önművelésre buzdította. A rendőrtisztviselő szaktanfolyamok, más néven rendőr akadémia lényegét a következőkben összegezte a Rendőr akadémia vezércikk ${ }^{34}$ írója: „[A]mi tapasztalatot, tudást, gyakorlati ismeretet egy hosszú munkás pályán összegyűjtött, azt csokorba kötve, készen adja át, az új generációnak, mely ilyenformán ismereteinek bővítését ott kezdje el, ahol az idősebb, tapasztaltabb, bölcsességben érett generáció elhagyta. Így érjük el a hószín magasságban ragyogó eszményt, a bölcs és kész rendőrideált." ${ }^{35}$

$\mathrm{Az}$ egyéves tanfolyamot teljesítő hallgatók a tanfolyam végén tiszti vizsgát tettek, és az elért eredmény alapján a végzetteket minősítették, rangsorolták. Aki eredménytelen vizsgát tett, csak külön indokolt esetben, engedéllyel vizsgázhatott újra. A sikeres tiszti vizsgát tett tisztviselőket véglegesítették, a sikerteleneket elbocsátották.

A 3720/1922. M. E. rendelet foglalkozott a felügyelői vagy fogalmazói karba más

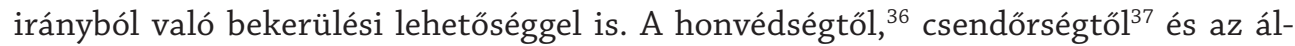
lamigazgatásból csak a rendőrtisztviselő tiszti, vagy felső tiszti vizsga eredményes letétele után lehetett kinevezni a pályázót. A felső tiszti vizsga eredményes teljesítése érdekében az erre kötelezetteknek hathónapos tanfolyami lehetőséget biztosítottak a felkészülésre. A rendelet pontosan meghatározta a kivételeket, a köz-, illetve harctéri szolgálat beszámíthatóságát, továbbá a rendelet előtt ideiglenesen kinevezett tisztviselőkre vonatkozó szabályokat.

A 3720/1922. M. E. rendelet végrehajtására gróf Klebelsberg Kunó belügyminiszter 1922. április 27-én kiadta a 66.898. B. M. rendeletét, a segédfogalmazók és segédfelügyelők próbaszolgálatának végrehajtására vonatkozó intézkedések tárgyában.

A végrehajtási rendeletben előírtak szerint a próbaszolgálatos segédfogalmazók és segédfelügyelők esküt tettek, és a kinevezett szolgálati helyen voltak kötelesek jelentkezni, s a szolgálatot megkezdeni. A próbaszolgálat célja az volt, hogy „a próbaszolgálatos segédfogalmazók, és segédfelügyelők a rendőri szolgálat minden ágáról gyakorlati tájékozódást nyerjenek". ${ }^{38}$ A próbaszolgálatosok a próbaszolgálat első három hónapjában az őrszemélyzet alakulatainál egyforma képzésben részesültek,

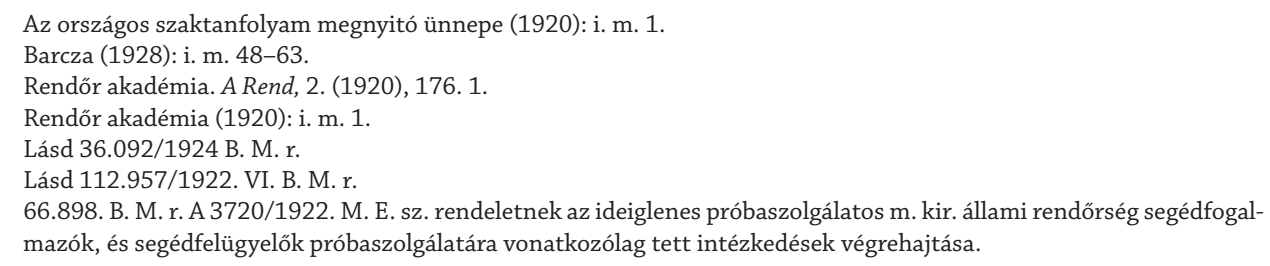


és megismerkedtek a rendőrség hatósági tevékenységével. Ezt követően két hónapig az őrszemszolgálatot, egy hónapig pedig az őrszobaparancsnok, a beosztott felügyelő és az őrszemélyzeti parancsnok kötelmeit gyakorolták. A tanfolyam során számviteli teendők elméleti és gyakorlati ismereteit is kötelesek voltak elsajátítani. A próbaszolgálat alatt a próbaszolgálatosok önállóan nem tevékenykedhettek, fegyverhasználati joguk nem volt. ${ }^{39}$

A próbaszolgálatosok előmenetelét a kapitányságvezető felügyelte, és róluk minősítést kellett írnia. Az oktatási év leteltével a minősítésüket a törzslapjukon felvezették, és a belügyminiszterhez felterjesztették.

A próbaszolgálat sikeres teljesítése után a szaktanfolyamok következtek, amelyek valamelyikének kötelező elvégzése feltétele volt a kinevezésnek, véglegesítésnek. A belügyminiszter a rendeletében a következő négyféle országos szintű szaktanfolyamot határozta meg:

- rendőrtisztviselői tiszti tanfolyam;

- rendőrtisztviselőket továbbképző tanfolyam;

- detektív és detektívfelügyelői tanfolyam;

- országos törzstisztképző tanfolyam. (A BM rendelet által említett „országos törzstisztképző tanfolyamra” nem készült végrehajtási rendelet. A szakirodalom a törzsképzést később „továbbképző tanfolyam” címen tartotta nyilván. $\mathrm{SJ})^{40}$

A tanfolyamok szervezése, lebonyolítása, anyagi biztosítása a szaktanfolyam parancsnokának a felelőssége, míg az összes szaktanfolyam élén a m. kir. Állami Rendőrség országos szaktanulmányi felügyelője, addig az egyes tanfolyamok élén a belügyminiszter által kinevezett igazgató áll. ${ }^{41} \mathrm{~A}$ m. kir. Állami Rendőrség országos szaktanulmányi felügyelőjének és a szaktanfolyamok parancsnokának hatáskörét, a tanfolyamok rendjét, a felügyelő és parancsnok, valamint az igazgató fegyelmezési jogköreit szintén a rendelet ${ }^{42}$ rögzítette.

\section{A rendörtisztviselöi tiszti tanfolyam és a vizsga ${ }^{43}$}

A tanfolyam célja a próbaszolgálatos segédfogalmazók és segédfelügyelők elméleti és gyakorlati szakmai felkészítése, tiszti vizsgára történő előkészítése volt. ${ }^{44}$ Ennek

\footnotetext{
Sallai (2020): i. m.

40 Sallai János: Rendőr-, rendőraltiszt-, rendőrtörzsaltiszt-képzés a m. kir. rendőrség államosítása után. Magyar Rendészet, 16. (2016), 6. 169-177.

41 18.80/1923. B.M. r. Utasítás a m. kir. állami rendőrség országos szaktanfolyamainak szervezetére, az országos szaktanulmányi felügyelő hatáskörének szabályozására és a tanfolyamok fegyelmi rendtartására vonatkozólag.

42 18.80/1923. B.M. r. Utasítás a m. kir. állami rendőrség... i. m.

43 Sallai (2020): i. m.

44 66.899/1922. B.M. r. A 3720/1922. M. E. sz. rendeletnek a rendőrtisztviselői tiszti tanfolyam és rendőrtisztviselői tiszti vizsgára vonatkozó intézkedései végrehajtása.
} 
érdekében elméleti előadásokat, írásbeli gyakorlatokat, rendőri intézményekben gyakorlati tapasztalatszerző utakat, helyszíni szemléken részvételi lehetőségeket, valamint testedzési alkalmakat biztosítottak a tanfolyam résztvevőinek.

A hallgatók sikeres felvételi vizsgát követően kerültek a tanfolyamra, amelynek előadásait, gyakorlati foglalkozásait kötelesek voltak látogatni. Részükre leckekönyvet állítottak ki. A tanfolyam idején a tanfolyamra beiskolázottaknak szabadság nem járt. A tanfolyam során rendes és speciális tantárgyak előadásait hallgatták.

Rendes tantárgyak:

- büntetőjog;

- magyar Btk. és egyéb törvények a büntettekről és vétségekről;

- bűnvádi perrendtartás és a 130.000 BM sz. utasítás;

- nyomozás segédeszközei;

- államrendészetre vonatkozó összes jogszabály;

- igazgatásrendészetre vonatkozó azon jogszabályok, amelyekben az eljárás a m. kir. rendőrséget illeti meg;

- büntető törvénykönyv, a kihágásokról és egyéb fontosabb kihágásokat megállapító törvényes jogszabályok;

- 65.000/1909. BM sz. rendelet és a rendőri büntető bíráskodás ügyviteli szabályai;

- az állami rendőrség szervezetére és hatáskörére vonatkozó szabályok;

- az állami rendőrség szolgálati és fegyelmi szabályzata;

- az állami rendőrség ügyviteli szabályzata, és az állami rendőrségi hivatalok pénzkezelése és számvitele tárgyában kiadott rendeletek;

- törvényszéki orvostan, elmekórtan;

- a magyar közjog, közigazgatási jog áttekintése;

- gyakorlati lélektan;

- tûzrendészet;

- közegészségtan és elsősegélynyújtás. ${ }^{45}$

Speciális tantárgyak: mindenkori tanterv szerint szervezve.

Ügyességi tantárgyak: vívás, pisztolylövés, úszás, lovaglás.

A rendelet szerint az előadásokat a gyakorlattal lehetőleg össze kellett kapcsolni. A hallgatók boncoláson is kötelesek voltak részt venni.

A tisztviselői tiszti vizsgát a tanfolyam végén díjtalanul letehették. A szóbeli vizsga témái a tanfolyam rendes tárgyaira támaszkodtak.

45 66.899/1922. B.M. r. A 3720/1922. M. E. sz. rendeletnek a... i. m. 


\section{Rendörtisztviselöket továbbképzö tanfolyam}

A rendôrtisztviselóket továbbképző tanfolyam, a rendőrtisztviselői tiszti tanfolyam kiegészítő része volt, amelynek fő célja: „a magasabb rendőri szakoktatás kifejlesztése és a tisztviselői tiszti vizsgára való előkészítés". ${ }^{46}$

A tanfolyamot két szakon, a fogalmazói és a felügyelői szakon indították. A tanfolyamra való jelentkezést a 3720/1922. M. E. sz. rendelet, majd annak megszervezését, lebonyolítását a 66.900. B. M. rendelet rögzítette.

A fogalmazói szak rendes tantárgyai:

- büntetőjog kapcsolatban a magyar Btk.-val;

- perrendtartás és a $130.000 \mathrm{BM}$ sz. utasítás;

- nyomozás segédeszközei;

- államrendészetre vonatkozó összes jogszabály;

- igazgatásrendészet, kapcsolatban a városrendészettel;

- Btk. a kihágásokról és egyéb fontosabb kihágásokat megállapító törvényes jogszabályok;

- a 65.000/1909. B.M. sz. rendelet és a rendőri büntető bíráskodás ügyviteli szabályai;

- az állami rendőrség szervezetére és hatáskörére vonatkozó szabályok;

- az állami rendőrség szolgálati és fegyelmi szabályzata;

- az állami rendôrség ügyviteli szabályzata, és az állami rendőrségi hivatalok pénzkezelése és számvitele tárgyában kiadott rendeletek;

- magyar közjog és közigazgatás jog;

- társadalomtan;

- a lélektan gyakorlati alkalmazása a rendőri szolgálatban;

- törvényszéki orvostan, elmekórtan;

- m. kir. honvédség, csendőrség, folyamőrség, vámőrség, pénzügyőrség szervezete;

- hivatalvezetés;

- rendőri oktatás a gyakorlatban. ${ }^{47}$

A felügyelői szak rendes tantárgyai:

- büntetőjog kapcsolatban a magyar Btk.-val;

- 130.000/1899 BM utasítás;

- nyomozás segédeszközei;

- államrendészetre vonatkozó összes jogszabály;

- igazgatásrendészet, kapcsolatban a városrendészettel;

- Btk. a kihágásokról és egyéb fontosabb kihágásokat megállapító törvényes jogszabályok;

66.900. B. M. r. A 3720/1922. M. E. sz. rendeletnek a rendőrtisztviselőket továbbképző tanfolyam és a rendőrtisztviselői felső tiszti vizsgára vonatkozó intézkedései végrehajtására.

47 66.900. B. M. r. A 3720/1922. M. E. sz. rendeletnek a... i. m. 
- 65.000/1909. B.M. sz. r.;

- az állami rendőrség szervezetére és hatáskörére vonatkozó szabályok;

- az állami rendőrség szolgálati és fegyelmi szabályzata;

- az állami rendőrség ügyviteli szabályzata, és az állami rendőrségi hivatalok pénzkezelése és számvitele tárgyában kiadott rendeletek;

- magyar közjog, közigazgatás jog;

- fegyverismertetés;

- m. kir. honvédség, csendőrség, folyamőrség, vámőrség, pénzügyőrség szervezete;

- külföldi rendőrségek;

- szolgálatvezetés;

- rendőri oktatás a gyakorlatban. ${ }^{48}$

Mindkét szakon a tantervvel összhangban szerveztek speciális előadásokat, és az ügyességi tantárgyak közül vívást, pisztolylövést és lovaglást.

A felső tiszti vizsgát rendszerint februárban, a két szakot elkülönítve, díjtalanul letehették. A szóbeli vizsga témái mindkét szakon az adott tanfolyam rendes tárgyaira támaszkodtak.

\section{Detektív- és detektívfelügyelöi tanfolyamok ${ }^{49}$}

A detektívvel szembeni általános és képzési követelményeket a 9270/1922. M. E. rendelet $^{50}$ állapította meg, amelynek végrehajtására belügyminiszteri rendeleteket adtak ki. A 18.881/1923-as BM ${ }^{51}$ rendelet különválasztotta a detektívtanfolyamot és detektívvizsgát, valamint a detektívfelügyelői tanfolyamot és detektívfelügyelői vizsgát.

\section{Detektívtanfolyam és detektívvizsga}

A detektívtanfolyam fő célja „az ideiglenes minősítésű detektívek szakszerű elméleti és gyakorlati kiképzése és a detektívszakvizsgára való előkészítés". 52

A detektívtanfolyam - mint a többi szaktanfolyam - a m. kir. állami rendőrség országos szaktanulmányi felügyelője felügyelete alatt állt. A résztvevő hallgatók tanfolyamra bekerülését, a tanfolyam szervezését, ügyvitelét és a tanulmányi ügyeket a 18.881/1923-as BM rendelet részletesen szabályozta.

A detektívtanfolyam rendes tantárgyai a következők voltak:

48 66.900. B. M. r.

49 Sallai (2020): i. m.

50 A m. kir. állami rendőrségnél alkalmazott detektívektől megkívánható elméleti és gyakorlati képzettség megállapítása és ezzel kapcsolatos intézkedések.

51 9270/1922. M. E. sz. rendeletnek detektívtanfolyamra és a detektívvizsgára, detektívfelügyelói tanfolyamra és detektívfelügyelői vizsgára, valamint detektív főfelügyelői minősítő vizsgára vonatkozó intézkedései végrehajtása.

52 9270/1922. M. E. sz. rendelet. 
- anyagi büntetőjog;

- alaki büntetőjog;

- kriminalisztika;

- kihágások és büntető bíráskodások;

- államrendészet;

- közigazgatási ismeretek;

- szervezési és szolgálati szabályzatok, különös tekintettel a detektív szolgálatára;

- elsősegélynyújtás. ${ }^{53}$

A rendes tantárgyak mellett a tanrend szerint speciális és gyakorlati tantárgyak is szerepeltek, amit a rendelet azonban nem nevesített.

Ugyanakkor nagyon fontosnak tartották, hogy az elméleti előadások anyagát gyakorlati példákkal támasszák alá az előadók. A detektívtanfolyam hallgatói kötelesek voltak boncoláson részt venni, és az elsősegély végrehajtását gyakorolni.

A detektívtanfolyamot a detektív szakvizsga követte, amely írásbeli és gyakorlati részből állt. Először írásbeli vizsgára került sor, amely főleg egy nyomozati ügy gyakorlati megoldására irányult.

Detektívfelügyelői tanfolyam és detektívfelügyelői vizsga ${ }^{54}$

A detektívfelügyelői tanfolyam a detektívtanfolyam kiegészítő része volt. Ebből adódóan a detektívtanfolyam lebonyolítására vonatkozó előírások a detektívfelügyelői tanfolyamra is vonatkoztak. A detektívfelügyelői tanfolyamra való bekerülésre a 9270/1922. M. E. sz. r. 14. §-a szerint a detektíveknek kérelem benyújtásával nyílt lehetősége. A detektívfelügyelői tanfolyam tantárgyai nagyrészt megegyeztek a detektívtanfolyam rendes tantárgyaival, kivétel, hogy a felügyelői tanfolyamon az elsősegélynyújtást nem oktatták. Ugyanakkor a detektívfelügyelői tanfolyamon a detektívtevékenység irányítására is alkalmas detektívfelügyelőket készítettek fel. Ezért különösen nagy hangsúlyt fektettek a gyakorlatra, a nyomozás és a bizalmi technika elsajátítására. Külön odafigyeltek, hogy a hallgatók gyors és önálló elhatározásra tudjanak jutni.

A detektívfelügyelői tanfolyam végén került sor az elméleti és gyakorlati részből álló detektívfelügyelői vizsgára. A vizsga lefolyása hasonló volt, mint a detektív szakvizsga, végrehajtására a 18.881/1923-as BM rendelet 18 . §-a volt az irányadó.

A titkos információgyűjtéssel ebben az időszakban egy külön erre a célra létrehozott detektívcsoport foglalkozott, amely a Belügyminisztérium épületének V. emeletén, egy elkülönített körletben, titokban működött. A csoport ekkor egy időben 80-100 telefon lehallgatására volt képes. A szélsőséges politikai csoportok múködé-

\footnotetext{
9270/1922. M. E. sz. rendelet.

54 Sallai (2020): i. m.
} 
sének ellenőrzésére pedig megszervezték a levélcenzúrát. Ezen a két területen dolgozó detektívek számára speciális felkészítést szerveztek. ${ }^{55}$

\section{Detektív föfelügyelői minősitésű vizsga}

A fenti vizsgát nem előzte meg tanfolyam, ezáltal tantárgyakhoz sem volt kötve. A detektív főfelügyelői minősítési vizsga célja volt „annak megállapítása, hogy a jelölt a detektívszolgálat terén rendelkezik-e azokkal a képességekkel és azokkal az ismeretekkel, amelyek a nagyobb detektívcsoportok vezetésére s általában detektívek között az ellenőrzés és a felügyelet gyakorlására a bizonyos esetekben és vonatkozásokban esetleg az állami rendőrség intézményének képviseletére is hivatott tisztviselőtől megkívánható”. ${ }^{56}$

S bár írásbeli és szóbeli jellegű volt a detektív főfelügyelői minősítési vizsga, a rendelet szerint a gyakorlatiasságnak dominálnia kellett.

A bemutatott képzési rendszer tanfolyamait és vizsgáit közvetlenül a rendeletek kiadása után, a gyakorlatban 1922. november 22-től bevezették. ${ }^{57}$ A tanfolyamokon heti két órában vívást is tanultak a hallgatók. Ezenkívül látogatást tettek a múzeumba, nyilvántartó hivatalba, fogház és toloncházba, és végül a törvényszéki orvostani intézetbe, ahol teljes boncolást mutattak be részükre. A tanfolyamok sikerét bizonyította, hogy mindig többen jelentkeztek a kiírt hallgatói helyekre, ezért sorrendet kellett felállítani, és csak a legjobbak kezdhették el a képzést. A résztvevők és az oktatók nevei nyilvánosak voltak, azokat a Rendőr (Magyar Rendőr) szakmai folyóiratban közzé tették. Az oktatók között szerepeltek a szakma legkiválóbb múvelői és kutatói, például Laky Imre, Rédey Miklós, Nagy Valér, Dorning Henrik, akik nemcsak magas színvonalú előadásaikkal, hanem az általuk írt, és mai napig fennmaradt tankönyvekkel is emelték a rendőrtisztképzés színvonalát. A rendészeti szakmai lapból megtudhattuk még, hogy az 1928. évi első félévben a detektívtanfolyam írásbeli záróvizsga tételei a következők voltak: ${ }^{58}$

- pénzhamisító banda leleplezése és az erről szóló jelentés;

- egy gyilkosság esettanulmánya;

- üzleti lopás felgöngyölítése.

A fenti vizsga szóbeli részénél Dr. Dorning Henrik főkapitány-helyettes, országos szaktanulmányi felügyelő is végig jelen volt. A vizsgán részt vett 27 hallgatóból

\footnotetext{
55 Boda József: „Szigorúan Titkos!? Nemzetbiztonsági almanach. Budapest, Zrínyi, 2016. 73.

56 9270/1922. M. E. sz. rendeletnek detektívtanfolyamra és a detektívvizsgára, detektívfelügyelői tanfolyamra és detektívfelügyelői vizsgára, valamint detektív főfelügyelői minősítő vizsgára vonatkozó intézkedései végrehajtása. 41. §.

57 A Rend, (1924), 96.1-2.

58 Rendör, (1928), május 5. 9.
} 
13 jeles, 11 jó, három elégséges osztályzatot érdemelt ki. ${ }^{59} \mathrm{~A}$ bizonyítványok kiosztása egy záró ünnepség keretén belül történt meg.

A detektívtanfolyamok magas színvonalát jelzi, hogy a korabeli szakmai újságunk, a Magyar Detektív 1927. márciusi számában a szaktanfolyamot következetesen detektív-főiskolának ${ }^{60}$ nevezték, sőt, egy alkalommal rendőr egyetemnek. A szaksajtó értékelése alapján „tudományos felkészültség dolgában párját ritkítja Európa szerte”61 a detektívtanfolyam. A minősítéshez valószínúleg hozzájárult, hogy Európában ekkor már több helyen volt rendőrtisztviselői felsőfokú képzés, például az Egyesült Királyságban Kriminológiai-, Rendőrtudományi Iskola, Olaszországban Rendőrségi Főiskola (egyetem), Ausztriában, Franciaországban és Belgiumban Kriminalisztikai Vizsgáló és Oktató Intézet, Németországban Rendőrségi Intézet.

\section{Rendőrtisztképzés a II. világháború után}

A fenti jó gyakorlatnak 1939-ben a II. világháború kirobbanása vetett véget. Az 1939-es honvédelmi törvény hatásaként militarizálódott ${ }^{62}$ a rendőrség is.

Magyarországon a II. világháború után, a politikai fordulatok nyomán a rendészet és a honvédelem altiszti és tisztikarát - méltánytalanul - szinte teljesen eltávolították. A rendőrtisztképzés fontosságát jelzi, hogy az Ideiglenes Nemzeti Kormány már az 1690/1945. sz. M. E. rendelete 8. §-ának (5) bekezdésében foglalkozott ezzel a témával. „A vármegyei főkapitányság keretében különleges rendőrségi alakulatok állíthatók fel, éspedig tanosztályok és tanfolyamok, amelyek keretén belül gondoskodni kell a rendőrség tagjainak demokratikus neveléséről is." ${ }^{3}$ A jelentős létszámhiányt tovább növelte, hogy sok korábbi rendőr és csendőr nyugatra szökött, illetve, hogy a csendőrséget feloszlatták. Elkezdődött a toborzás, amelynek során képzetlen emberek tömkelegét kellett felvenni. Ennek következtében 1945 után a rendőrség kötelékébe kerülő munkás és paraszt fiatalok szinte általános és szakmai műveltség nélkül vették kezükbe a fegyvert azzal a céllal, hogy a háború utáni hihetetlen méreteket öltő bűnözéssel minden területen felvegyék a harcot. E folyamat részeként a baloldali hatalomnak szükségessé vált egy új tisztikar kinevelése, amelyet szovjet mintára hoztak létre. Ennek a kívánalomnak a teljesítésére az ezt követő évtizedek alatt folyamatosan hoztak létre és szüntettek meg rendőrtisztképző intézeteket, iskolákat. Ezzel párhuzamosan különböző időtartamban szerveztek gyorstalpaló képzéséket, például őrsparancsnoki tanfolyamokat.

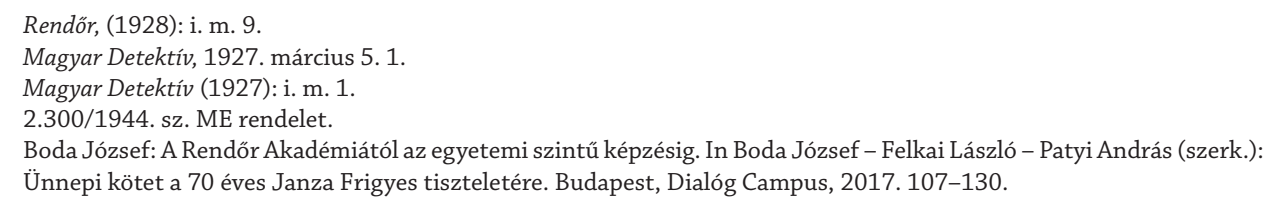


„A hiányzó képzettség pótlására, az Ideiglenes Nemzeti Kormány 1690/1945. ME. rendelete alapján, a belügyminiszter utasítására eleinte helyi szinten indítottak néhány hetes tanfolyamokat. Önképzésen alapuló, havi 2-3 napos összevonásokkal, konzultációkkal segített záróvizsgával végződő levelező rendszerű felkészüléseket. Ez nem pótolta azonban a szakoktatást. Ezért az Ideiglenes Kormány a háború előtt is múködött központi irányítású szaktanfolyam újraindítását, és teljesen új iskolarendszer megindítását szorgalmazta." ${ }^{4}$

A személyi állomány gyors feltöltését segítette elő a belügyminiszter által kiadott 147.332/1945. IV.-12. sz. rendelet ${ }^{65}$ is, amely a szakképzés megszervezésére vonatkozott. A szaktanfolyam

„célja, hogy a rendőrség újonnan kinevezett tagjai és közegei a szolgálati út ellátásához megkívánt szakszerű képzettséget és gyakorlati készültséget tervszerű tanulmányi rendben legalább nagy általánosságban megszerezhessék. A tájékoztató tanfolyam befejeztével a hallgatók vizsgát tesznek, majd szolgálati helyeikre bevonulva rendes szolgálati teendőik ellátása mellett továbbképzik magukat s ezt követően a budapesti főkapitányság, illetőleg a vidéki főkapitányság vezetőjének előterjesztésére előkészítő tanfolyamra kerülnek". ${ }^{66}$

A nagy hiányra való tekintettel Budapesten két tiszti szaktanfolyamot szerveztek, és plusz a nyomozó tisztek részére egy harmadikat. Ugyanebben az időben az ősparancsnokok ${ }^{67}$ gyors képzésére is egy céltanfolyam gyors megszervezésével, felállításával reflektált az akkori belügyi vezetés.

1948-ban a Magyar Államrendőrség Tiszti Akadémiáját röviden Rendőr Akadémiának (RAK) hívták, és azt 1949-ben a Rendőr Törzstisztképző Főiskola ${ }^{68}$ felállítása követte. A RAK megszervezését elrendelő BM rendelet szerint, a RAK a következő célból jött létre: „[H]ogy az államrendőrség tisztikarának utánpótlását biztosítsam, rendőrtiszti főiskolát létesítek azzal a rendeltetéssel, hogy elméletileg és gyakorlatilag képzett, a rendőri szolgálat minden ágában felhasználható rendőrtiszteket neveljen."69

A miniszteri rendeletből jól kivehető a szándék, hogy már ekkor egy gyakorlatorientált rendörtiszti föiskolát akartak alapítani, amelyre azonban az akkori helyzet miatt csak később kerülhetett sor. Az első évfolyam indítása 1948. február 1-jén (az akkori Köztársaság Napján) valósult meg. Az egyéves képzés tantárgyai a következők voltak:

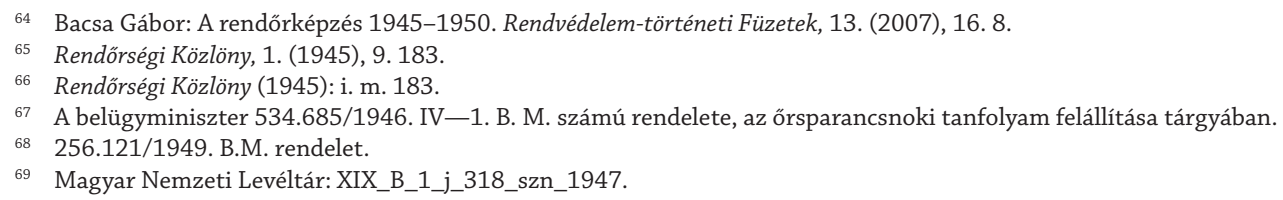


- jogi ismeretek (közjog, közigazgatásjog, magánjog);

- büntetőjog (anyagi és alaki);

- kihágásrendészet;

- nyomozástan;

- igazgatásrendészet (tűzrendészet, közlekedésrendészet);

- államrendészet és politikai rendészet;

- szolgálati és fegyelmi szabályzat;

- szervezeti és ügyviteli szabályzat;

- törvényszéki orvostan és közegészségtan;

- rendőrgazdászati ismeretek;

- történelem- és társadalomtudományi ismeretek;

- földrajz (leíró és politikai);

- magyar nyelv és irodalom;

- karhatalmi kiképzés (lőkiképzés, tereptan, fegyvertan, karhatalmi szabályzat);

- sportkiképzés (birkózás, cselgáncs...). ${ }^{70}$

A tantárgyakból jól látható, hogy a bevonult hallgatók szakmai felkészítése mellett az általános múveltségre is gondot fordítottak. A rendelet mellékletében azt is rögzítették, hogy az egyéves időtartamú RAK-on nem oktatnak nemzetközi jogot, lovas és gépkocsi kiképzést, orosz nyelvet, mennyiségtant és mértant, műszaki ismereteket, gépírást, rendőrségtörténetet, szervezést, vezetést, évfolyam értekezleteket. ${ }^{71}$ A RAK tervezésénél is szóba került a Rendőrtiszti Főiskola ${ }^{72}$ elnevezés, és a fennmaradt sajtóforrások alapján az első tiszti kibocsátásnál az akkori párt szócsöve, a Szabad Nép is következetesen a Rendőrtiszti Főiskola elnevezést alkalmazta. Az a törzstiszti képzés érdekessége, hogy néhány hónap alatt végzett rendőrtisztek őrvezetőből, őrmesterekből századosok, őrnagyok, alezredesek lettek. ${ }^{73}$

Ezt követően eltérő időtartalommal, de RAK néven zajlott a rendőrtisztképzés. Ezt igazolja a 257.340/1949. IV/1-d. BM. számú rendelet „a rendőrség szervezetében rendőrtisztképző iskola felállítása tárgyában, ” amellyel a belügyminiszter a rendőrség szervezetében „Rendőrtisztképző Iskola” elnevezéssel, budapesti székhellyel (XII. ker. Böszörményi út 21-ben), 1949. augusztus 1-jei kezdéssel tisztképző iskolát hozott létre. A Rendőrtisztképző Iskola 1950-1956 között működött. ${ }^{74}$

A szocialista időszak alatt a rendészet területén is kötelező volt a szovjet minta átvétele, így a Szovjetunióban meghonosodott domináns állambiztonság a magyar belügyi szerveknél is teret nyert. Így a szovjet mintára megszervezett állambiztonság tisztjeit kezdetben néhány hetes vagy hónapos tanfolyamokon képezték ki. Később a Rendőr Akadémián tanultak, majd ezt az 1949-től Felix Edmundovics Dzerzsinszkij

\footnotetext{
70 Magyar Nemzeti Levéltár: XIX_B_1_j_311_1084_1947.

71 Magyar Nemzeti Levéltár: XIX_B_1_j_311_1084_1947.

72 Törzstisztekké és tisztekké avatta Kádár elvtárs a Rendőrtiszti Főiskola végzett hallgatóit. Szabad Nép, (1949), 287.

3 Törzstisztekké és tisztekké avatta Kádár elvtárs a Rendőrtiszti Főiskola végzett hallgatóit (1949): i. m.

74 Virányi Gergely: Határőrizeti és határrendészeti tisztképzés 1903-2011. Budapest, Dialóg Campus, 2019. 58.
} 
nevét viselő Állambiztonsági Tisztképző Iskolán ${ }^{75}$ folytatták. Ezzel párhuzamosan az ÁVH vezetőit a Szovjetunióban képezték ki.

Az 1956-os forradalom után a belügyi vezetés számára egyértelmüvé vált, hogy a rendőrtiszti állománnyal szemben a magasabb követelmény támasztásának érdekében, magasabb színvonalú képzésre van szükség, amely csak hosszabb időtartamú iskolán lehetséges. Ennek következtében a Honvédelmi Tanács 1959-ben elrendelte a Rendőr Akadémia ${ }^{76}$ felállítását. (A RAK 1947-től többször előfordult mint képző intézmény nevének rövidítése, de eltérő időszakokban, eltérő tartalmat takart. S.J.)

Már ekkor felmerült az igény, hogy az általános tantárgyak oktatását egyetemi szintűvé kell tenni. A Rendőr Akadémia elismerését jelentette, hogy jogi és közigazgatástudományi egyetemekre az itt végzett hallgatók könnyítéssel bejuthattak, ám maga a RAK csak érettségit adott. 1961-től a megszűnt Dzerzsinszkij Akadémia helyett az állambiztonsági képzést a RAK-on folytatták.

1962-1971 között a BM Határőrség, BM Karhatalom és kormányőrség középfokú tiszti továbbképzésére létrehozták a BM Akadémiát. Később a karhatalmi és határőr tisztképzés a honvédségnél az Egyesített Tiszti Iskolán, majd a Kossuth Lajos Katonai Főiskolán önálló tagozat, majd később tanszék keretein belül folyt.

A folyamatosan fellépő tiszthiány pótlásának megoldásáért Kerepestarcsán felállították a BM Tartalékos Tisztképző Iskolát, amely 1967 és 1989 között funkcionált. A sorkatonai idejük alatt itt felkészítettek később a BM valamely területén hivatásos szolgálatot vállalhattak.

Az 1960-as években végbement kül- és belpolitikai változások, a követelmények folyamatos emelkedése a rendőrtisztképzésben is új kihívásokat hozott magával. A BM Idegen Nyelvi Főiskola és BM Rendőrtiszti Akadémia 1960-ban történt formális egyesítésével létrejött a Rendőrtiszti Akadémia - továbbra is RAK rövidítéssel.

Az 1950-es évek után, az 1960-as évek végére a társadalom felépült a II. világháború romjaiból, és egy magasabb színvonalú, hatékonyabb rendőrséget igényelt. Ennek egyik politikai megnyilvánulása, hogy az MSZMP 1969. november 28-ai határozata - értékelve a BM addigi tevékenységét - kiemelte a „belügyi szervek káderállománya képzettségének a magasabb színvonalra emelését” ${ }^{77}$ Emellett a határozat a következő elvárásokat fogalmazta meg a BM-mel szemben:

- Jobban tartson lépést a társadalom fejlődésével, elemezze a bünözést, állítsa előtérbe a bűnmegelőzést.

- Tegyen különbséget a rendszer kritikusai és az ellenségei között.

- Határozottan intézkedjen az állam ellen támadókkal szemben.

- Fordítson nagyobb gondot a népgazdaság védelmére.

- Határozottabban lépjen fel a visszaesők és az erőszakos garázda magatartást tanúsítókkal szemben.

75 Simon László: A rendôrtisztképzés 25 éve. Budapest, (k. n.), 1969. 7.

76 Simon (1969): i. m. 14.

77 A Rendőrtiszti Főiskola szerepe a belügyminisztérium előtt álló feladatok megoldásában. Interjú Györök Ferenc rendőr ezredes elvtárssal Rendőrtiszti Főiskola parancsnokával. Belügyi Szemle, (1971), 8. 29-34. 
- Szélesítsék és mélyítsék a tömegekkel a kapcsolatot.

- Tekintsék fő feladatnak a szocialista törvényesség maradéktalan érvényesítését.

- Fordítsanak kiemelt figyelmet a káderképzés és a vezetés magasabb színvonalra való emelésére. ${ }^{78}$

A fenti MSZMP-feladatszabás hatást gyakorolt a belügyi vezetésre, amelynek jeleire nem kellett sokat várni. A korszak politikai intézményrendszerének müködéséből adódóan a kérdéssel legközelebb a Belügyminisztérium Kollégiuma foglalkozott, amely 1970. május 8-ai ülésén döntött a Rendőrtiszti Főiskola (RTF) létrehozásáról, a rendőrtisztképzés színvonalának emeléséről, és az ezt kiszolgáló belügyi tudományos tevékenység központi megszervezéséről.

\section{Összefoglalás}

A rendőrtisztviselő-, illetve rendőrtisztképzés hosszú és göröngyös utat járt be a 20. században, amelynek főbb állomásai: 1922. november 22., az első rendőrtisztviselői szaktanfolyam évnyitója; 1948. február 1., a Rendőr Akadémia megnyitása; majd 1971. szeptember 25., a Rendőrtiszti Főiskola átadása. Amíg 1922-t követően a rendőrtisztviselői szaktanfolyamokra való bejutás a magas követelmények teljesítése esetén valósulhatott meg, addig 1948 után, a Rendőr Akadémiákra - az ismert történelmi körülmények miatt - az alacsonyabban iskolázott munkás és paraszt fiatalok kerültek be. Az 1960-as években bekövetkezett színvonal-emelkedés miatt a politikai vezetés és a társadalom egyaránt a rendőrtisztekkel szemben folyamatosan egyre magasabb követelményeket támasztott, aminek következtében döntés született a rendőrtisztképzés főiskolai intézményi formában történő megszervezésére és önálló elhelyezésben történő megoldására.

\section{FELHASZNÁLT IRODALOM}

Androvicz Gábor: A magyar rendőrképzés fejlődése a dualizmus időszakában. Magyar Rendészet, 18. (2018), 1. 29-37.

Bacsa Gábor: A rendőrképzés 1945-1950. Rendvédelem-történeti Füzetek, 13. (2007), 16. 7-14. Online: http://epa.oszk.hu/02100/02176/00002/pdf/RTF_16_007-014.pdf

Barcza Pál: A Magyar Királyi Rendôrség szervezete és ügyvitele. Rendőriskolák tananyagának tára. V. kötet. Budapest, BM, 1928.

Boda József: „Szigorúan Titkos!? Nemzetbiztonsági almanach. Budapest, Zrínyi, 2016.

Boda József: A Rendőr Akadémiától az egyetemi szintű képzésig. In Boda József - Felkai László - Patyi András (szerk.): Ünnepi kötet a 70 éves Janza Frigyes tiszteletére. Budapest, Dialóg Campus, 2017.

78 Györök Ferenc: A szocialista rendőrtisztképzés három évtizede. Belügyi Szemle, 16. (1978), 9. 3-12. 
Boda József (föszerk.): Rendészettudományi szaklexikon. Budapest, Dialóg Campus, 2019.

Concha Győző: A rendôrség természete és állása szabad államban. Székfoglaló értekezés. Budapest, Magyar Tudományos Akadémia, 1901.

Dorning Henrik: Berlini rendőrkiállítás. A Rend, (1926), 77. 2.

Györök Ferenc: A szocialista rendőrtisztképzés három évtizede. Belügyi Szemle, 16. (1978), 9. 3-12. Karvasy Ágoston: A politicai tudományok rendszeresen előadva I-III. Győr, Streibig, 1843-1844.

Laky Imre: Rendőrközegek tankönyve. Budapest, Pátria, 1906.

Magyar Detektív, (1927), március 5. 1.

Az országos szaktanfolyam megnyitó ünnepe. A Rend, 2. (1920), 176. 1.

A Rend, (1924), 96.1-2.

Rendőr, (1928), május 5.

Rendőr akadémia. A Rend, 2. (1920), 176. 1.

A rendőrség intézményei. Közbiztonság, (1911), 42. 521-527.

Rendôrségi Közlöny, 1. (1945), 9.

A Rendőrtiszti Főiskola szerepe a belügyminisztérium előtt álló feladatok megoldásában. Interjú Györök Ferenc rendőr ezredes elvtárssal Rendőrtiszti Főiskola parancsnokával. Belügyi Szemle, (1971), 8. 29-34.

Rédey Miklós: Rendőri szakoktatás. Közbiztonság, 18. (1911), 7. 98.

Rédey Miklós: Rendőri szakoktatásunk. Rendőri Lapok, 9. (1902), 16. 121-122.

Sallai János: A magyar rendészeti képzés története 1922-2017. Rendőr altiszt (tiszthelyettes) és rendőrtiszt képzés a XX-XXI. században. In Czene-Polgár Viktória - Zsámbokiné Ficskovszky Ágnes (szerk.): Mérföldkövek az adó- és vámigazgatás történetéből. Válogatott tanulmányok az évfordulók tükrében. Budapest, Magyar Rendészettudományi Társaság Vám- és Pénzügyőri Tagozat, 2017. 86-123. Online: https://tinyurl.hu/lT9v

Sallai János: A magyar rendészettudomány etablációja és akkreditációja. In Ruzsonyi Péter (szerk.): Fenntartható biztonság és társadalmi környezet tanulmányok III. Budapest, Ludovika Egyetemi Kiadó 2020. 13-130.

Sallai János: Első rendészetelméleti szakközlöny folyóiratunk: a „Közbiztonság” (1869). In Gaál Gyula - Hautzinger Zoltán (szerk.): A határrendészettől a rendészettudományig. Pécs, MHT Határőr Szakosztály Pécsi Szakcsoportja, 2016. 271-274.

Sallai János: Rendőr-, rendőraltiszt-, rendőrtörzsaltiszt-képzés a m. kir. rendőrség államosítása után. Magyar Rendészet, 16. (2016), 6. 169-177.

Sallai János: Rendőr altiszt- és tisztképzés a m. kir állami rendőrségnél az államosítás (1920) után. In Varga János (szerk.): A határrendészeti tisztképzés negyedszázada. Budapest, Dialóg Campus, 2017. 239-253.

Simon László: A rendörtisztképzés 25 éve. Budapest, (k. n.) 1969.

Törvényhatósági szabályrendeletek és főkapitányi rendeletek gyưjteménye, kieg. a székesfővárosi $\mathrm{m}$. kir. áll. rendőrség szervezetét, hatáskörét és müködését szab. rendeletekkel. Összeáll. és kiad.: Krecsányi Kálmán. Bp. Müller K. ny. 1894.

Virányi Gergely: Határôrizeti és határrendészeti tisztképzés 1903-2011. Budapest, Dialóg Campus, 2019. Online: https://nkerepo.uni-nke.hu/xmlui/bitstream/handle/123456789/13022/Hatarorzeti_es_hatarrendeszeti_tisztkepzes_1903_2011.pdf?sequence=1 


\section{ABSTRACT \\ The Training of Commissioned Law Enforcement Officers until the Establishment of the Police College}

János SALLAI

In parallel with the development of modern Hungarian policing, the nationalisation of the police in the capital and then in the countryside began. The existence of a unified state police required the training of police officers based on a standardised training of officers, which was established in 1922. This marked the beginning of the advanced training of the inspectors, draftsmen and detective faculties, which lasted until the end of the Second World War. After the Second World War, Hungary came under the Soviet sphere of interest, as a result of which the Soviet model was implemented in the police force as well. Thus, the preparation of the working and peasant youth to become police officers was realised first through a crash course, and then from 1948 at Police Academies. As a result of social development, the demand for policing has also increased, to which the political leadership responded in 1971 with the establishment of the Police College.

Keywords: police officer, law enforcement officer, education, training, supervisor, detective, draftsman, police, vocational course 